\title{
BARIERY I ZAKRES AUTOMATYZACJI Z PERSPEKTYWY TREŚCI PRACY
}

DOI: $10.33141 / p o .2021 .3 .01$

\author{
Marek Jabłoński
}

Przegląd Organizacji, Nr 3(974), 2021, s. 3-11 www.przegladorganizacji.pl ๑) Towarzystwo Naukowe Organizacji i Kierownictwa (TNOiK)

\section{Wprowadzenie}

W spółcześnie realizowane procesy pracy warunkowane są wieloma czynnikami, m.in.: innowacjami technologicznymi, rozwojem gospodarki cyfrowej (urządzania mobilne, drukowanie 3D, Internet Rzeczy, BigData), zmianami w globalnym podziale pracy (w tym offshoringiem), zmianami $w$ sposobie organizacji firm i instytucji rynkowych, zmianami demograficznymi, zmianami modeli konsumpcji (OECD, 2017a, s. 12). Kluczową jednak determinantą zmian otoczenia biznesowego jest postęp technologiczny, który wpływa na: procesy społeczno-gospodarcze (Avant, 2014), rozwój sektorów gospodarki opartej na wiedzy (Godin, 2006), innowacje produktowe i procesowe, ale także procesy i modele biznesowe (Blaschke i in., 2017) oraz struktury przedsiębiorstw (Snow i in., 2017). Współcześnie dokonujący się postęp $\mathrm{w}$ technologiach produkcji dóbr i usług wiązany jest $\mathrm{z}$ nastaniem nowej ery, określanej w literaturze przedmiotu jako: druga era maszyn (Brynjollfsson, McAfee, 2014), trzecia rewolucja przemysłowa (Rifkin, 2011) czy Przemysł 4.0 (Schwab, 2017). Bez względu na występujące $\mathrm{w}$ literaturze przedmiotu określenia zachodzących zmian $\mathrm{w}$ otoczeniu przedsiębiorstw należy przyjąć, że postęp technologiczny zmienia treść pracy wykonawców zaangażowanych $\mathrm{w}$ realizację procesów produkcyjnych i administracyjno-biurowych (Autor, 2015; Martyniak, 1992; Mokyr, 2002), modyfikuje popyt na wiele zawodów i profesji, generując jednocześnie zupełnie nowe obszary aktywności człowieka (OECD, 2017a). Zagadnienie to staje się szczególnie istotne $\mathrm{w}$ dobie aktualnej automatyzacji procesów produkcji dóbr i usług. Automatyzuje się bowiem już nie tylko procesy produkcyjne, ale coraz powszechniej procesy administracyjno-biurowe, w tym lokowane w tzw. centrach usług wspólnych.

Celem artykułu jest przedstawienie społecznych i biznesowych uwarunkowań automatyzacji procesów pracy oraz barier i zakresu stosowania tego typu rozwiązań z perspektywy treści pracy. W ramach tak zdefiniowanego zamierzenia wyjaśniono znaczenie pojęcia automatyzacji także w konfrontacji z terminami korespondującymi. Na bazie badania bibliometrycznego ukazano rosnącą liczbę publikacji dotyczących koncepcji automatyzacji. Dokonano także identyfikacji zjawisk wyjaśniających wpływ postępu technicznego na treść pracy, w szczególności wymagania stawiane pracownikom $\mathrm{w}$ procesach pracy. Zaprezentowano także podejścia umożliwiające szacowanie $\mathrm{z}$ jednej strony potencjalnego zakresu automatyzacji procesów pracy, z drugiej zaś barier automatyzacji z perspektywy treści pracy ${ }^{1}$.

\section{Automatyzacja - istota i pojęcia pokrewne}

A utomatyzacja w sensie ogólnym odnosi się do zastępowania pracy człowieka przez maszyny i urządzenia, w szczególności substytucji ręcznych czynności prowadzenia (kierowania, sterowania) procesów technologicznych czynnościami samoczynnymi (bez udziału człowieka) (Brzeziński, 2002). Substytucja ta może dotyczyć pewnych czynności człowieka, względnie grup czynności wypełniających funkcje stanowiska pracy i/lub fazy produkcji dóbr i usług. W takim znaczeniu automatyzacja jako rezultat dokonującego się postępu technicznego procesów pracy, koresponduje z pojęciami: mechanizacja i robotyzacja.

Pojęcie mechanizacji stosowali już przedstawiciele tzw. okresu przedtaylorowskiego. Przykładowo Ch. Babbage (1832) i A. Ure (1835) mechanizację wiązali z substytucją przez maszyny i urządzenia niebezpiecznych i bardzo męczących fizycznie prac człowieka. Natomiast zgodnie z współczesną literaturą przedmiotu, mechanizacja oznacza wprowadzenie do produkcji dóbr i usług maszyn zastępujących siłę człowieka, w tym pracę ręczną lub silę pociągową zwierząt. Polega na stosowaniu urządzeń mechanicznych, dzięki czemu człowiek oddziałuje na maszynę zasilaną przez odrębne źródło energii, obrabiającą przedmiot pracy (Biczyński, Miedziński, 1991, s. 84). A zatem mechanizacja odnosi się do instrumentalizacji umożliwiającej realizację pewnych czynności wykonawczych i umysłowych (heurystycznych) w procesach pracy (Martyniak, 1992, s. 84). Natomiast robotyzacja oznacza zastępowanie pracy ludzkiej robotami i to zarówno $\mathrm{w}$ procesach produkcyjnych, jak i administracyjno-biurowych. Roboty stosowane w procesach technologicznych to roboty przemysłowe, obejmujące manipulator $\mathrm{z}$ napędami oraz układ sterowania $\mathrm{z}$ panelem programowania i interfejsem komunikacyjnym (Pilat i in., 2018). Natomiast oprogramowanie komputerowe umożliwiające zautomatyzowany transfer i przetwarzanie informacji $\mathrm{w}$ środowisku wirtualnym określane jest jako RPA (Robotic Process Automation) 
(Sobczak, 2019). W obydwu przypadkach sterowanie dokonuje się poprzez wprowadzony przez człowieka program bądź przez zbiór ogólnych reguł, które za pomocą technik sztucznej inteligencji zostają przełożone na działania robota.

W takim znaczeniu automatyzację można interpretować jako etap następujący po mechanizacji (Noble, 1984, s. 36; Martyniak, 1992, s. 17; Simon, 2007, s. 200). A zatem mechanizacja występuje, gdy stosowane są maszyny w celu zmniejszenia obciążenia pracą robotnika, natomiast automatyzacja wówczas, gdy maszyna całkowicie przejmuje zadania wykonywane przez robotnika (Richard, 2005). Automatyzacja może być częściowa lub pełna, gdy zapewniony jest samoczynny, a także elastyczny przebieg procesu wytwórczego bez ingerencji człowieka (Musso, 2013, s. 301). W związku z tym robotyzacja oznacza pełną automatyzację, tj. zautomatyzowane wykonanie określonych zadań oraz procesów.

$\mathrm{Na}$ marginesie warto jednak wspomnieć, że popularyzacja pojęcia automatyzacji nastąpiła w latach 50 . XX wieku, zwłaszcza na skutek działalności Ford Motor Company. I tak, w 1947 roku uruchomiono w tej korporacji Automation Department odpowiedzialny za projektowanie elektromechanicznych, hydraulicznych i pneumatycznych mechanizmów przemieszczania komponentów i części umożliwiających połączenie autonomicznych maszyn oraz zwiększenie tempa pracy. Natomiast w 1950 roku uruchomiono pierwszą automatyczną fabrykę silników (Noble, 1984, s. 67). Wprawdzie automatyzacja $\mathrm{w}$ tym przypadku odnosiła się jedynie do przemieszczania środków pracy, niemniej jednak popularyzacja tego zjawiska zaowocowała intensyfikacją badań naukowych oraz szerszą publiczną dyskusją na temat skutków postępującej automatyzacji. Przykładowo P. Naville (1968), na podstawie przeprowadzonych badań w latach 1958-59, dokonał identyfikacji społecznych skutków automatyzacji w przemyśle francuskim, natomiast J. Bright (1958) przeprowadził podobne badania $\mathrm{w}$ odniesieniu do przemysłu amerykańskiego. Z kolei 19 sierpnia 1964 roku prezydent USA Lyndon B. Johnson powołał komisję (National Commision on Technology, Automation, and Economic Progress), której celem była identyfikacja wpływu rozwoju technologii, w tym sztucznej inteligencji na gospodarkę i rynek pracy. Rezultaty prac komisji opublikowano w 1966 roku, a ich kluczowym wnioskiem była konstatacja, że automatyzacja i rozwój technologii, w tym sztuczna inteligencja, nie muszą eliminować pracy dla człowieka, dodatkowo jeśli tylko właściwie się do niej przygotować, wówczas zjawiska te mogą wspierać wzrost gospodarczy i społeczny dobrobyt (Autor, 2015).

\section{Koncepcja automatyzacji w świetle analizy bibliometrycznej}

0 ceny rozwoju koncepcji automatyzacji dokonano na podstawie badań bibliometrycznych, które przeprowadzono w odniesieniu do pojęć automatyzacji oraz korespondujących, tj. mechanizacja i robotyzacja. Dane wejściowe do badań pozyskano z baz publikacji naukowych Scopus (www.scopus.com) i Sciencedirect (www. sciencedirect.com) w okresie od 24 kwietnia do 4 maja 2021 roku. Przeprowadzone badania obejmowały dwa okresy, tj. lata 1959-2020 dla publikacji indeksowanych w bazie Scopus oraz lata 1998-2020 dla publikacji w bazie Sciencedirect (niemożliwe było pozyskanie kompletnych danych dla analiz bibliometrycznych za lata wcześniejsze). Badania przeprowadzono w języku angielskim.

$\mathrm{Na}$ etapie planowania badań niezbędne stało się rozstrzygnięcie kilku istotnych kwestii. Pierwsza dotyczyła wyboru jednego z dwóch występujących w języku angielskim tłumaczeń terminu mechanizacja ('mechanization' - American English i 'mechanisation' - British English). I tak, w badaniu zastosowano słowo 'mechanization', które występuje zdecydowanie częściej w publikacjach naukowych. Kolejną kwestią było przyjęcie terminu 'robot' jako podstawa wyszukiwania publikacji naukowych dotyczących robotyzacji. Rozstrzygnięcie to stało się niezbędne, aby do zbioru identyfikowanych w badaniach publikacji włączyć także te odnoszące się do terminów zbieżnych znaczeniowo z robotyzacją, tj. 'robotic', 'robot', 'robotized,' 'robotised', 'robotization,' 'robotisation'. Wreszcie $\mathrm{w}$ celu ograniczenia liczby publikacji jedynie do tych z zakresu nauk o zarządzaniu zdecydowano identyfikować tylko te, które mają w swoim opisie bibliograficznym, tj. w tytule, słowach kluczowych i streszczeniu, także wyrażenie 'management'.

W konsekwencji badanie bibliometryczne przeprowadzono dla następujących trzech par terminów: 'automation and management', 'mechanization and management', 'robot and management' (rys. 1). Dla pogłębienia prowadzonych analiz podjęto także próbę zawężenia otrzymanych wyników do kilku obszarów badawczych, tj. 'Business, Management and Accounting', 'Decision Sciences', 'Social Sciences', 'Economics, Econometrics and Finance'. Przy czym o ile w bazie Scopus możliwe okazało się grupowanie publikacji względem wszystkich wytypowanych obszarów badań (rys. 2), tak w przypadku bazy Sciencedirect nie można było zawęzić publikacji do obszaru badań 'Economics, Econometrics and Finance' (rys. 3).

Przeprowadzone analizy wskazują na stały wzrost liczby publikacji naukowych w bazach Scopus i Sciencedirect dotyczących badanego zakresu tematycznego w całym analizowanym okresie. Przy czym od początku lat 80 . XX wieku daje się zauważyć wzrastającą dynamikę liczby publikacji odnoszących się do terminów: 'automation and management', natomiast z początkiem XXI wieku liczbę publikacji zawierających terminy: 'robot and management'. Z przeprowadzonych analiz wynika, że stosunkowo najmniejszym zainteresowaniem o umiarkowanej względnie stałej dynamice wzrostu cechowała się tematyka wyznaczona przez publikacje zawierające terminy: 'mechanization and management' (rys. 1), także po zawężeniu ich do poszczególnych analizowanych obszarów badawczych (rys. 2 i 3). Natomiast publikacje naukowe odpowiadające terminom: 'automation and management' znacznie przewyższają liczbę publikacji 


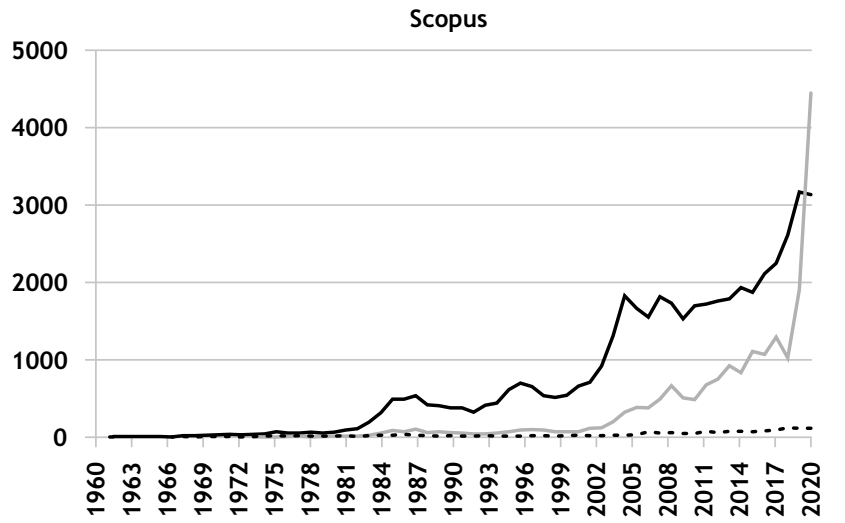

- Automation (management)

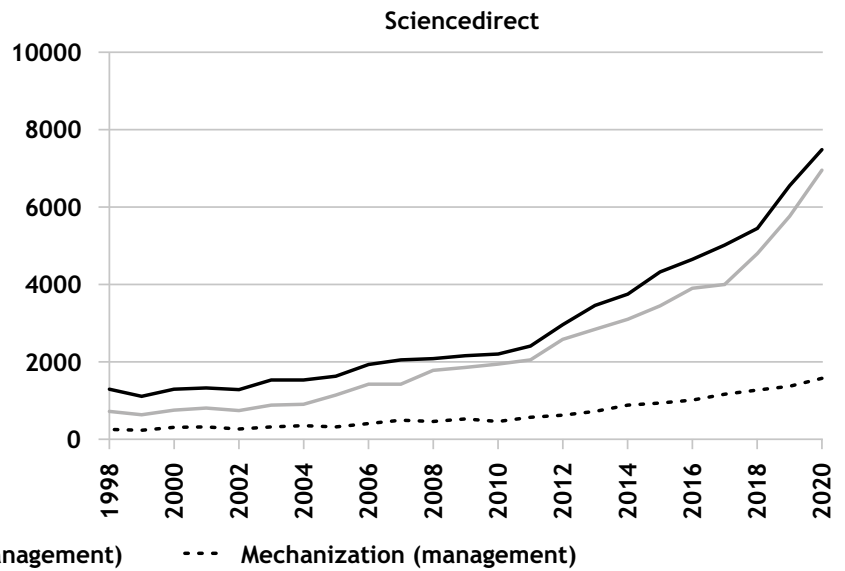

Rys. 1. Liczba zidentyfikowanych publikacji w bazach Scopus i Sciencedirect dla terminów: 'automation and management', 'robot and management', 'mechanization and management'

Źródło: opracowanie własne
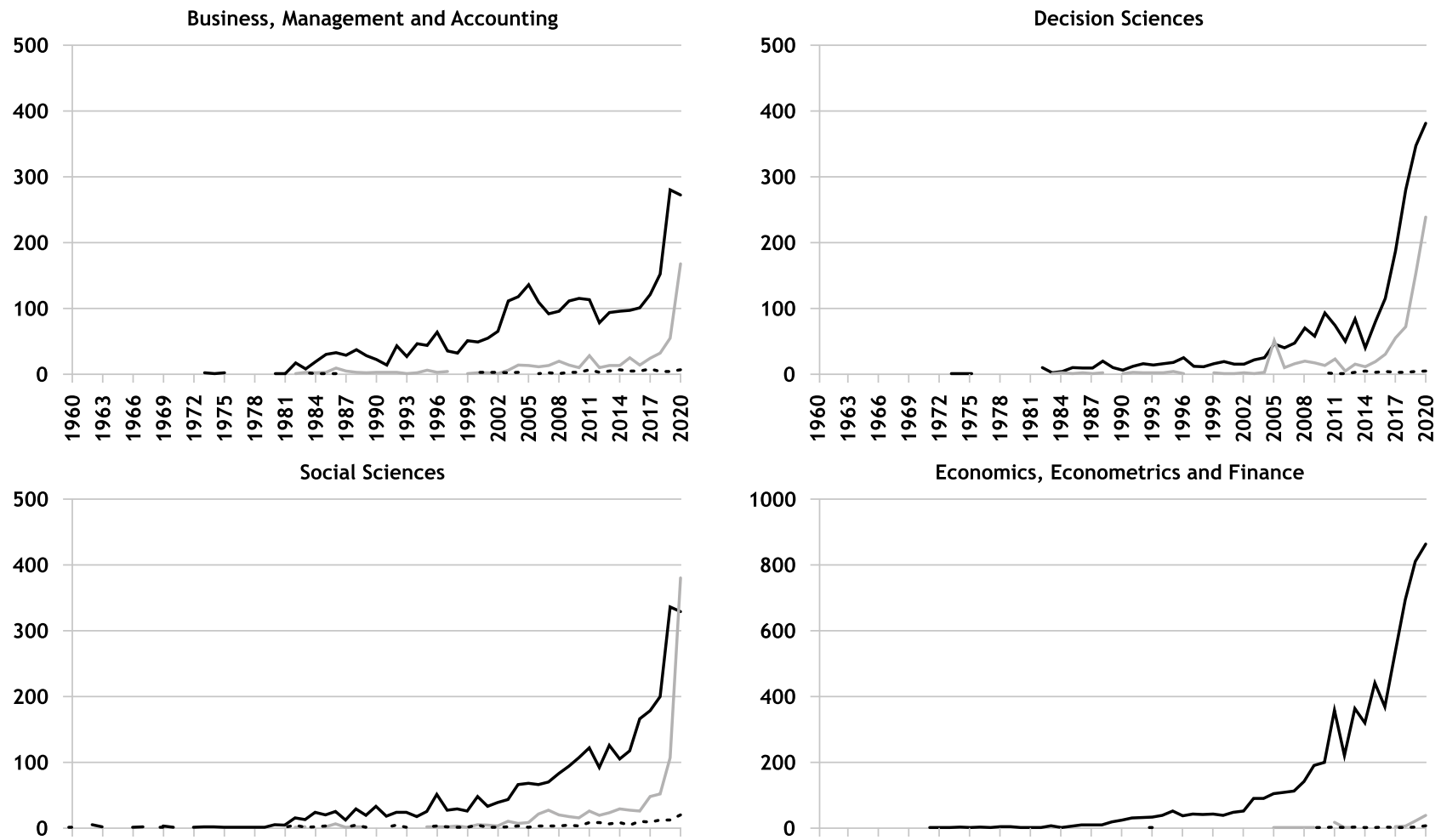

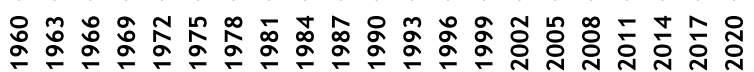

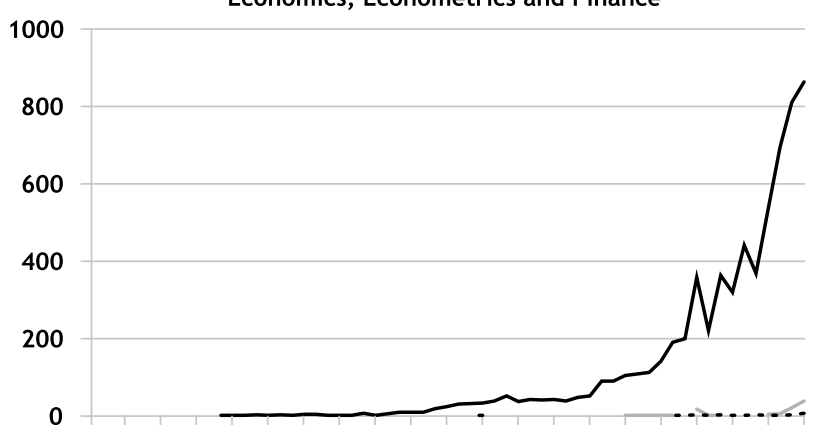

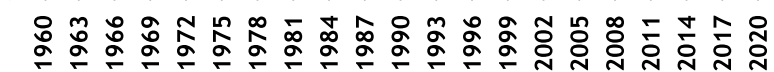

- Automation (management)

Robot (management)

-.. Mechanization (management)

Rys. 2. Liczba zidentyfikowanych publikacji w bazie Scopus dla terminów: 'automation and management', 'robot and management', 'mechanization and management' zawężonych dla obszarów: Business, Management and Accounting, Decision Sciences, Social Sciences, Economics, Econometrics and Finance

Źródło: opracowanie własne

naukowych zawierających pozostałe analizowane terminy, tj. 'mechanization and management' oraz 'robot and management', także w odniesieniu do poszczególnych obszarów badawczych. Jedyny wyjątkek w tym względzie stanowią publikacje naukowe zidentyfikowane w bazie Scopus dla 2020 roku odnoszące się do obszaru Social Sciences, w szczególności w 2020 roku liczba publikacji dla terminów 'robot and management' przewyższyła liczbę publikacji zawierających terminy 'automation and management' (rys. 2).
Interesujące wnioski można sformułować, analizując wzajemną dynamikę wzrostu publikacji naukowych dla analizowanych par terminów w odniesieniu do poszczególnych obszarów badawczych. I tak, w obszarze Economics, Econometrics and Finance dominują publikacje odnoszące się do terminów: 'automation and management', jednocześnie ilość publikacji dla pozostałych analizowanych terminów jest marginalna. W obszarze Decision Sciences w ramach bazy Scopus odnotowano stosunkowo znikomą liczbę publikacji zawierających 

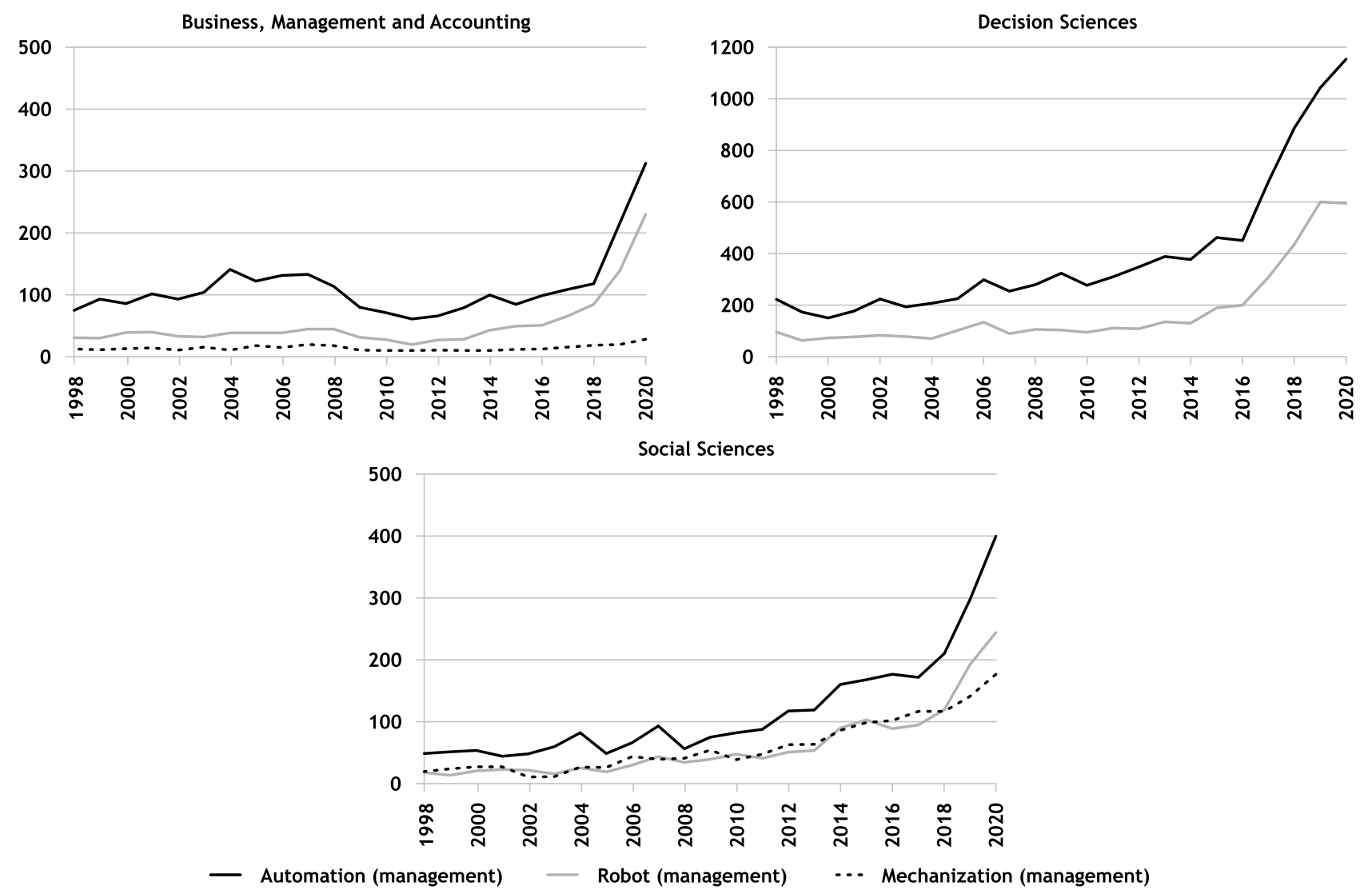

Rys. 3. Liczba zidentyfikowanych publikacji w bazie Sciencedirect dla terminów: 'automation and management', 'robot and management', 'mechanization and management' zawężonych dla obszarów: Business, Management and Accounting, Decision Sciences, Social Sciences w latach 1998-2020

Źródto: opracowanie wtasne

terminy: 'mechanization and management', natomiast $\mathrm{w}$ bazie Sciencedirect nie udało się zidentyfikować żadnej publikacji plasującej się w tym obszarze badawczym. Z przeprowadzonych analiz wynika także, że począwszy od 2016 roku daje się zauważyć dynamiczny przyrost publikacji odnoszących się do terminów 'robot and management', w tym zwłaszcza w obszarach: Business, Management and Accounting oraz Social Sciences. Dodatkowo w 2020 roku w obydwu tych obszarach identyfikowanych $\mathrm{w}$ ramach bazy Scopus zanotowano obniżenie liczby publikacji zawierających terminy: 'automation and management' przy jednoczesnym wzroście liczby publikacji odnoszących się do terminów: 'robot and management?

\section{Wpływ postępu technicznego na treść pracy}

A utomatyzacja stanowi odwzorowanie postępu technicznego w procesach pracy, a zatem możliwe jest na bazie bogatej literatury przedmiotu zidentyfikowanie zjawisk opisujących wpływ postępu technicznego, a ściślej automatyzacji na treść pracy, tj. wymagania stawiane pracownikom w procesach pracy, w tym:

- tzw. unskill-biased technical change,

- tzw. skill-biased technical change,

- tzw. talent-biased technical change.
Efekt pierwszy (tzw. unskill-biased technical change) dotyczy postępu technicznego dokonującego się zwłaszcza w XIX wieku, który powodował wzrost produktywności pracowników o stosunkowo niskich umiejętnościach (Autor i in., 2003). Na skutek wdrażanych technologii warsztat rzemieślniczy zastąpiono fabryką z wymiennymi częściami i linią montażową, natomiast wykwalifikowanych rzemieślników pracownikami o stosunkowo niskich umiejętnościach (Mokyr, 2002). Efekt ten możliwy jest także do zidentyfikowania we współczesnych sektorach bazujących na niskokwalifikowanych pracownikach (Esposto, 2008), względnie gdy analizowane są poszczególne grupy zawodowe. Przykładowo, koszt przygotowania i przeszkolenia operatora maszyn i urządzeń niskiego i średniego poziomu mechanizacji w porównaniu do operatora maszyn sterowanych numerycznie wynosi około 12 do 1, co oznacza, że jeżeli cztery lata zajmuje przeszkolenie operatora tradycyjnych maszyn i urządzeń, to operatora maszyn sterowanych numerycznie można przyuczyć do wykonywania pracy w ciągu czterech miesięcy (Bravermann, 1998, s. 139-144). Przeprowadzone badania we Francji w latach 1958-1959 nad rozwojem automatyzacji w przemyśle wykazały, że zatrudnieni bezpośrednio w procesach produkcji to $\mathrm{w} 80 \%$ niewykwalifikowani pracownicy (Naville, 1968, s. 18-35). Podobne wnioski sformułowano $\mathrm{w}$ badaniach przeprowadzonych $\mathrm{w}$ USA, w szczególności analizowano zmianę treści pracy na po- 
szczególnych 17 stopniach mechanizacji i wykazano, że umiejętności operatorów początkowo rosną (1-5 poziom mechanizacji), a następnie istotnie się obniżają (6-17 poziom mechanizacji) (Bright, 1958, s. 181).

Efekt tzw. skill-biased technical change został zidentyfikowany $\mathrm{w}$ amerykańskim przemyśle $\mathrm{z}$ początkiem XX wieku. W szczególności zaawansowanie technologiczne związane $\mathrm{z}$ przejściem $\mathrm{z}$ systemu produkcji z końca XIX wieku na systemy fabryczne $\mathrm{z}$ silnikami elektrycznymi pozwoliło na automatyzację operacji, zwłaszcza w zakresie przemieszczania surowców i półproduktów (transport, linia produkcyjna), tj. operacji dotychczas wykonywanych przez niewykwalifikowanych pracowników (Goldin, Katz, 1996). Na skutek wdrażania w przemyśle maszyn kontrolowanych przez pracownika zmysłem wzroku i słuchu następował wzrost umiejętności pracowniczych wymaganych na stanowiskach produkcyjnych, rosnący popyt na umiejętności konserwacyjne zapewniające bezawaryjność maszyn i urządzeń, wzrastające zapotrzebowanie na wysokokwalifikowanych inżynierów i techników (O’Connor, Lunati, 1999). Wzrost wymagań w zakresie umiejętności pracowniczych warunkowany jest także rozwojem technologii informacyjno-komunikacyjnych, które zwiększają produktywność pracowników wykonujących zadania stanowiskowe polegające na: abstrakcyjnym myśleniu, kreatywności i rozwiązywaniu problemów (Autor, Acemoglu, 2011). Efekt ten można zilustrować skutkiem wdrażania bankomatów w amerykańskim sektorze bankowym. Otóż, bankomaty zaczęto wdrażać w latach 70 . XX wieku i tylko w latach 1995-2010 ich liczba wzrosła czterokrotnie - z ok. 100000 do ok. 400000 szt. Można by przypuszczać, iż zmiany te ograniczyły zatrudnienie w tym sektorze. Okazało się jednak, że w tym okresie zatrudnienie pośród kasjerów bankowych wzrosło z 500000 do 550 000, aczkolwiek ich udział w zatrudnieniu ogółem się obniżył. Stosowanie bankomatów pozwoliło wyeliminować prace rutynowe na stanowiskach kasjerów z jednoczesnym wzbogaceniem zadań stanowiskowych o zadania związane ze sprzedażą, marketingiem i relacjami z klientami (Autor, 2015, s. 6-7).

Efekt tzw. talent-biased technical change polega na diagnozowanym aktualnie wzroście zapotrzebowania na ekspertów i utalentowanych pracowników, zwłaszcza w obszarze robotyki, sztucznej inteligencji i analizy informacji (Brynjolfsson, McAfee, 2014). Postępy w technologii informacyjno-komunikacyjnej ostatnich kilku dekad zapewniły pracodawcom tańsze maszyny i oprogramowanie, które mogą zastąpić ludzi w zadaniach wymagających średnich umiejętności, tj. księgowość, praca biurowa i powtarzalne zadania produkcyjne, które coraz częściej realizowane są przez komputery, roboty i inne technologie cyfrowe (OECD, 2017b, s. 10). Aktualne technologie umożliwiają automatyzację wielu umiejętności, które jeszcze niedawno były domeną jedynie aktywności człowieka. Na przykład przeprowadzone badania wykazały, że komputery osiaggają 97\% skuteczność w czytaniu z ruchu ust, podczas gdy człowiek tylko 52\% (Manyika i in., 2017, s. 12). W takim znaczeniu substytucja pracy człowieka przez technologie jest oczywista, choć istotniejsza wydaje się komplementarność. Na przykład stosowanie bezzało- gowych dronów w lotnictwie wojskowym wyeliminowało szereg zadań wcześniej wykonywanych przez ludzi (piloci, mechanicy itp.). Jednocześnie powstało wiele nowych zadań w zakresie konserwacji, zdalnego sterowania, analizy danych i cyberbezpieczeństwa. Przykładowo obsługa bezzałogowego drona typu Predator czy Reaper sił powietrznych USA, przelatujących nad Syrią, wymaga 30-osobowego personelu, natomiast analiza danych zebranych przez drony wymaga pracy kolejnych co najmniej 80 osób. W 2015 r. amerykańskie siły powietrzne nie dysponowały odpowiednio wyszkolonym personelem, który mógłby obsadzić wszystkie te stanowiska, dlatego mieli do czynienia z paradoksalnym kryzysem: nie mogli zapewnić załogi bezzałogowym dronom (Harari, 2018, s. 51).

\section{Potencjalny zakres automatyzacji procesów pracy}

W spółczesna literatura przedmiotu zawiera podejścia umożliwiające szacowanie potencjalnego zakresu automatyzacji (Autor i in., 2003) oraz ryzyka automatyzacji poszczególnych zawodów (Frey, Osborne, 2013).

D. Autor, F. Levy i R. Murnone (2003) opracowali metodologie szacowania potencjalnego zakresu prac podlegających automatyzacji. Zgodnie z proponowanym podejściem, w grupie realizowanych zadań stanowiskowych można wyszczególnić: prace rutynowe oraz nierutynowe. Prace rutynowe, charakterystyczne dla wielu stanowisk robotniczych i administracyjno-biurowych odnoszą się do działań sekwencyjnych, ustrukturalizowanych, opartych na regułach i procedurach oraz posiadają stosunkowo wysoki potencjał automatyzacji. Coraz częściej są kodyfikowane w oprogramowaniu komputerowym i zlecane do wykonywane przez maszyny lub przesyłane drogą elektroniczną do innych podmiotów otoczenia lub zagranicznych placówek poprzez outsourcing i offshoring. Prace nierutynowe, w tym: poznawcze (abstrakcyjne) i ręczne, polegają na: rozwiązywaniu problemów, kreatywności, wymagają adaptacji interpersonalnej i środowiskowej do określonych zmiennych sytuacyjnych oraz oceny informacji. Prace nierutynowe nie podlegają automatyzacji, gdyż trudno jest jak na razie zapisać je w formie instrukcji wielowariantowych sposobów pracy maszyny (Autor, Acemoglu, 2011, s. 1076-1079). Przyjęta typologia prac umożliwia identyfikację 4 grup stanowisk względnie jednorodnych z punktu widzenia treści pracy (tab. 1).

Z przeprowadzonych badań wynika, że w gospodarce USA w latach 1959-2012 nastąpił wzrost udziału zatrudnienia na stanowiskach, gdzie praca jest nierutynowa, w tym: ręczna i poznawcza, oraz spadek zatrudniania na stanowiskach administracyjno-biurowych, sprzedawców i stanowiskach produkcyjnych, gdzie praca jest rutynowa (Autor, 2015). Podobne tendencje diagnozowane są w odniesieniu do innych rozwiniętych gospodarek ${ }^{2}$, np. Niemiec (Dustmann i in., 2009), Danii (Terzidis i in., 2017), Australii (Coelli, Borland, 2016), Kanady (Green, Sand, 2015) oraz grup gospodarek badanych łącznie, np. 31 krajów europejskich (Wang i in., 2015), USA, Japonii i 9 krajów UE (Michaels i in., 2014). 
Tabela 1. Typologia prac

\begin{tabular}{|l|l|l|}
\hline \multicolumn{1}{|c|}{ Rodzaj prac } & \multicolumn{1}{|c|}{ Grupy stanowisk } & \multicolumn{1}{c|}{ Funkcja główna grup stanowisk } \\
\hline Nierutynowe abstrakcyjne & Menedżerowie, specjaliści, technicy & Rozwiązywanie problemów, ocena informacji, kreatywność \\
\hline Rutynowe poznawcze & $\begin{array}{l}\text { Sprzedawcy, pracownicy } \\
\text { administracyjno-biurowi }\end{array}$ & $\begin{array}{l}\text { Proste prace z informacjami polegające na: organizowaniu, } \\
\text { przechowywaniu, odzyskiwaniu i manipulowaniu informacjami }\end{array}$ \\
\hline Rutynowe ręczne & $\begin{array}{l}\text { Stanowiska produkcyjne, naprawcze, } \\
\text { rzemieślnicze }\end{array}$ & Bazujące na regułach i algorytmach działania fizyczne \\
\hline Nierutynowe ręczne & Sektor usługowy & $\begin{array}{l}\text { Prace fizyczne wymagające zdolności adaptacji interpersonalnej } \\
\text { i środowiskowej }\end{array}$ \\
\hline
\end{tabular}

Źródło: opracowanie własne na podstawie: Autor, Acemoglu, 2011, s. 1077

Tabela 2. Czynniki i zmienne stanowiskowe stanowiące bariery automatyzacji

\begin{tabular}{|c|c|c|}
\hline $\begin{array}{l}\text { Bariery } \\
\text { automatyzacji }\end{array}$ & Zmienna & Charakterystyka \\
\hline \multirow{3}{*}{$\begin{array}{l}\text { Percepcja } \\
\text { i manipulacja }\end{array}$} & Zręczność palców & $\begin{array}{l}\text { Zdolność do precyzyjnego koordynowania ruchów palców jednej lub obu rąk do } \\
\text { uchwycenia, manipulowania lub złożenia bardzo małych przedmiotów }\end{array}$ \\
\hline & Zręczność manualna & $\begin{array}{l}\text { Możliwość szybkiego poruszania dłonią, dłonią z ramieniem lub dwoma rękami, aby } \\
\text { uchwycić, manipulować lub zmontować obiekty }\end{array}$ \\
\hline & $\begin{array}{l}\text { Ciasna przestrzeń, niewygodna } \\
\text { pozycja ciała }\end{array}$ & $\begin{array}{l}\text { Częstotliwość realizacji zadań stanowiskowych w niewielkiej przestrzeni, przy niewygodnej } \\
\text { pozycji ciała }\end{array}$ \\
\hline \multirow{2}{*}{ Kreatywność } & Oryginalność & $\begin{array}{l}\text { Możliwość wymyślania nowych pomysłów na dany temat lub sytuację, lub udoskonalenie } \\
\text { sposobów rozwiązania problemów }\end{array}$ \\
\hline & Sztuki piękne & $\begin{array}{l}\text { Znajomość teorii i technik wymaganych do komponowania, wykonywania utworów muzyki, } \\
\text { tańca, sztuki wizualnej, dramatu i rzeźb }\end{array}$ \\
\hline \multirow{4}{*}{$\begin{array}{l}\text { Inteligencja } \\
\text { społeczna }\end{array}$} & Spostrzegawczość społeczna & Świadomość reakcji innych i zrozumienie, dlaczego reagują w określony sposób \\
\hline & Negocjowanie & Znajdowanie konsensusu i podejmowanie prób godzenia różnic \\
\hline & Perswazja & Przekonywanie innych, aby zmienili zdanie lub zachowanie \\
\hline & Pomoc i troska o innych & $\begin{array}{l}\text { Zapewnienie pomocy osobistej, pomocy lekarskiej, emocjonalnej, wsparcie lub opieka } \\
\text { osobista dla innych, tj. współpracowników, klientów, pacjentów }\end{array}$ \\
\hline
\end{tabular}

Źródto: Frey, Osborne, 2013, s. 31

W badaniach diagnozuje się także ryzyko automatyzacji poszczególnych zawodów. Wykorzystuje się w tym zakresie metodologię autorstwa C. Freya i M. Osborne’a (2013), polegającą na: identyfikacji czynników oraz zmiennych stanowiących bariery automatyzacji (tab. 2), a następnie w oparciu o te czynniki klasyfikacji zadań w ramach zawodów ujętych w bazach danych rynków pracy poszczególnych gospodarek. Zgodnie z niniejszą metodologią, szczególnie trudno automatyzacji podlegają prace wymagające stosunkowo wysokiego poziomu:

- percepcji i manipulacji przedmiotami i informacjami,

- kreatywności oraz

- inteligencji społecznej.

Z przeprowadzonych badań wynika, że w kolejnych dwóch dekadach $47 \%$ wszystkich zatrudnionych w gospodarce USA będzie się plasować w grupie wysokiego ryzyka związanego z automatyzacją (Frey, Osborne, 2013). Podobnie odsetek ten dla innych gospodarek kształtuje się na względnie wysokim poziomie, np. Finlandia - 35\%, Norwegia - 33\% (Pajarinen i in., 2015), Europa 54\% (Bowles, 2014), Singapur - 25\% (Lee, 2017).
Przykładowo zawody najbardziej narażone na automatyzację to telemarketerzy - 99\%, księgowi i audytorzy - 94\%, sprzedawcy detaliczni - 92\%, agenci nieruchomości $-86 \%$, edytorzy tekstu i maszynistki $-81 \%$ oraz pracownicy sektora rolnego. Najniższe ryzyko występuje w przypadku ustawodawców i wyższych urzędników oraz pracowników nauk biologicznych i służby zdrowia (Frey, Osborne, 2013, s. 68-72).

Ostatnie szacunki w oparciu o metodologię C. Freya i M. Osborne’a wskazują, że w gospodarce USA do 5\% wszystkich zawodów może zostać zautomatyzowane całkowicie przy użyciu aktualnych technologii, natomiast około $60 \%$ wszystkich stanowisk ma co najmniej $30 \%$ zadań poddających się automatyzacji (rys. 4). Działania najbardziej podatne na automatyzację obejmują czynności fizyczne w wysoce ustrukturyzowanych i przewidywalnych środowiskach, a także gromadzenie i przetwarzanie danych. W USA tego typu prace stanowią 51\% prac realizowanych w gospodarce (Maryika i in., 2017, s. 8). Przykładowo gromadzenie danych (64\% potencjał automatyzacji i $17 \%$ czasu pracy w gospodarce) i ich 


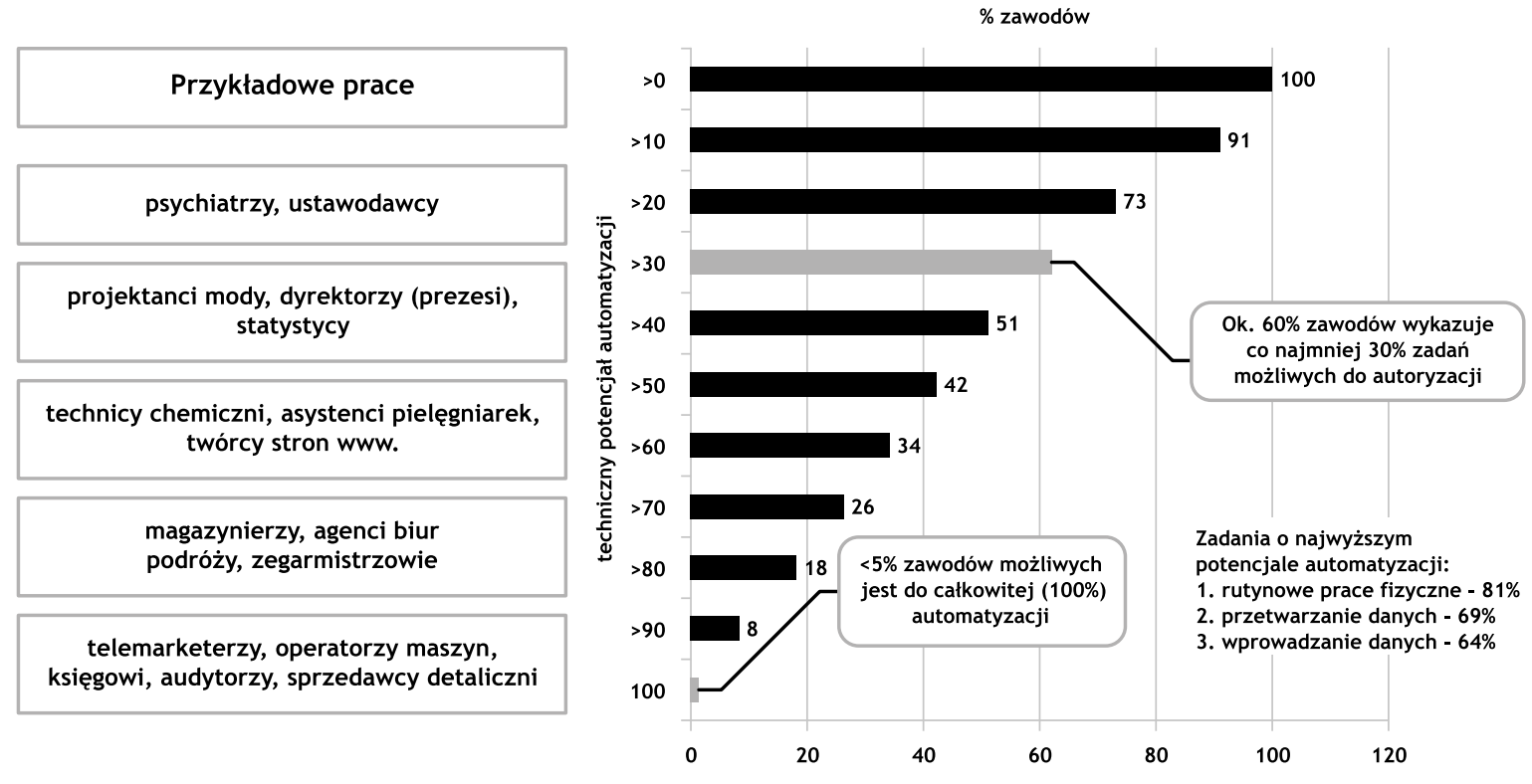

Rys. 4. Potencjalny zakres automatyzacji pracy

Źródło: opracowanie własne na podstawie: Maryika i in., 2017

przetwarzanie (69\% potencjał automatyzacji i $16 \%$ czasu pracy w gospodarce) są realizowane w prawie wszystkich sektorach, a polegają na: administrowaniu danymi kadrowymi, płacowymi, transakcyjnymi, umieszczaniu danych $\mathrm{w}$ formularzach instytucji ubezpieczeniowych, kredytowych, bankowych, zdrowotnych (Maryika i in., 2017, s. 44).

W oparciu o metodologię C. Freya i M. Osborne’a (2013) szacowane jest także ryzyko automatyzacji procesów biurowych ze szczególnym uwzględnieniem sektora finansowego, w tym tzw. centrów usług wspólnych. Dotychczas bowiem upowszechniony był pogląd, iż automatyzacja $\mathrm{w}$ tym sektorze eliminuje przede wszystkim proste prace $\mathrm{z}$ informacjami wymagające niskich kompetencji, aktualnie jednak dostrzegalny jest także spadek zatrudnienia wśród profesjonalistów sektora finansowego. Przykładowo liczba bankierów, handlowców, traderów i innych pracowników na Wall Street, tzw. front office, w okresie 2010-2014 obniżyła się o $16 \%$. A przewidywania KPMG donoszą, że do 2026 roku do $100 \mathrm{mln}$ tej grupy pracowników zostanie zastąpionych zautomatyzowanymi procesami (Cline i in. 2016, s. 14). Z przeprowadzonych analiz wynika, że automatyzacja stanowi zagrożenie dla wielu zawodów sektora finansowego, jednak to księgowi w największym stopniu są zagrożeni postępującą robotyzacją procesów biurowych. Analizy Deloitte pozwoliły zidentyfikować stanowiska w zakresie funkcji finansowej o niskim, średnim i wysokim ryzyku automatyzacji. I tak (Nagarajah, 2016):

- niskie prawdopodobieństwo automatyzacji dotyczy prac wymagających wyższych kompetencji, polegających na: planowaniu i doradztwie strategicznym, analizach i controllingu finansowym, w tym stanowisk: specjalistów w zakresie zarządzania projektami biznesowymi i finansowymi, dyrektorów i menedżerów finansowych,

- średnie prawdopodobieństwo automatyzacji wiąże się ze stanowiskami: kierownicy i dyrektorzy zakupów,
- wysokie prawdopodobieństwo automatyzacji odnosi się do relatywnie prostych prac w obszarze księgowości, związanych z: rozliczaniem transakcji, wierzytelności i płatności, w tym stanowisk: menedżer płac, administrator finansowy, kontroler kredytowy, kierownik kont finansowych, technicy finansowi i księgowi, menedżer finansowy.

W obliczu postępującej automatyzacji księgowi, aby minimalizować ryzyko uznania ich profesji za możliwą do automatyzacji, powinni być zorientowani na pełnienie w większym zakresie ról strategicznych i analitycznych. Automatyzacja zmienia charakter pracy współczesnego specjalisty ds. finansów, w szczególności w miejsce zredukowanych prac rutynowych pojawiają się zadania strategiczne, wymagające interakcji $\mathrm{z}$ interesariuszami, a obejmujące ocenę informacji i formułowanie wniosków w celu poprawy wyników biznesowych.

\section{Podsumowanie}

$\mathbf{P}$ rzeprowadzone badania bibliometryczne oraz analiza literatury przedmiotu potwierdzają rosnące zainteresowanie badawcze automatyzacją, zwłaszcza od lat 80. XX wieku, natomiast robotyzacją w ostatnich dwudziestu latach. Aktualnie wysoka ranga automatyzacji z perspektywy funkcjonowania i rozwoju przedsiębiorstw oraz całych sektorów gospodarki powoduje, że coraz częściej traktuje się ją jako szczególny rodzaj zmiany organizacyjno-technologicznej. Zmiana ta przekształca warunki funkcjonowania przedsiębiorstw oraz stymuluje pojawienie się nowych warunków pracy dla człowieka i zespołów ludzkich. Automatyzacja powoduje zastąpienie umiejętności człowieka maszynami, które to maszyny jednocześnie wymagają jeszcze więcej umiejętności człowieka w zakresie ich obsługi, konserwacji czy napraw. Wraz z postępem automatyzacji praca człowieka uległa istotnym zmianom. Przykładowo początkowo człowiek był odpowiedzialny za bezpośrednią produkcję 
dóbr i usług, później za obsługę maszyny i urządzeń produkcyjnych, wreszcie aktualnie coraz częściej staje się projektantem systemów nadzorujących pracę maszyn i urządzeń. Inżynier przestał pracować przy maszynach i urządzeniach, zaczął natomiast poprzez programy i algorytmy wydawać komendy, jakie części określona maszyna ma zaprojektować i wyprodukować. Praca menedżera w coraz mniejszym zakresie polega na bezpośrednim nadzorowaniu procesów produkcyjnych, w tym pracy zespołów ludzkich. W coraz większym zakresie odnosi się do pracy z informacjami, m.in. liczbami, raportami czy systemami operacyjnymi umożliwiającymi podejmowanie decyzji.

W sensie ogólnym zadania niepodlegające substytucji przez dokonującą się automatyzację należy traktować jako komplementarne. Zasoby ludzkie jako relatywnie rzadsze na tle stosowanej technologii, stawać się będą cenniejsze w całym łańcuchu tworzenia wartości. Rodzi to jednak pewne konsekwencje z perspektywy sprawności systemu zarządzania, zwłaszcza zasobami ludzkimi organizacji. Menedżerowie motywowani normatywem optymalizacji kosztów działalności, podejmując decyzję o automatyzacji poszczególnych procesów pracy, stają $\mathrm{w}$ obliczu podejmowania decyzji kadrowych związanych $z$ jednej strony z przesunięciami pracowników, których praca zastępowana jest przez stosowane unowocześnienie. Zmiana organizacyjno-technologiczna wiąże się również z koniecznością włączenia $\mathrm{w}$ procesy pracy zasobów ludzkich reprezentujących wyższe czy też nowe umiejętności, niestosowane dotą $\mathrm{w}$ organizacji. W takim znaczeniu szczególnie użyteczne może się okazać narzędzie diagnostyczne umożliwiające szacowanie potencjalnego zakresu prac podlegających automatyzacji oraz identyfikację czynników i zmiennych stanowiskowych stanowiących bariery automatyzacji. Wypracowanie takiego narzędzia $\mathrm{w}$ formie metodyki, następnie stosowanej w organizacji w zestawieniu z planami automatyzowania procesów pracy może okazać się pomocne w projektowaniu rozwiązań umożliwiających dostosowanie zasobów ludzkich organizacji do antycypowanych zmian technologicznych. Rozwiązań, które pozwolą skutecznie wdrażać obrane warianty technologiczne, minimalizując negatywne społeczne skutki automatyzacji.

\section{dr hab. Marek Jabłoński, prof. uczelni Uniwersytet Ekonomiczny w Krakowie Kolegium Nauk o Zarządzaniu i Jakości ORCID: 0000-0002-5464-7147 e-mail: marekj@uek.krakow.pl}

\section{Przypisy}

1) Źródło finansowania: dotacja na utrzymanie potencjału badawczego Kolegium Nauk o Zarządzaniu i Jakości Uniwersytetu Ekonomicznego w Krakowie

2) Wzrost udziału zatrudnienia pośród zarówno nisko, jak i wysoko kwalifikowanych pracowników identyfikowany począwszy od lat 90. XX literatura przedmiotu odnosi także do zjawiska polaryzacji pracy (Goos i in., 2007, Terzidis i in., 2017, s. 5).

\section{Bibliografia}

[1] Autor D.H., Levy F., Murnane R.J. (2003), The Skill Content of Recent Technological Change: An Empirical Exploration, „Quarterly Journal of Economics”, Vol. 116, No. 4, pp. 1279-1333.

[2] Autor D.H. (2015), Why Are There Still so Many Jobs? The History and Future of Workplace Automation, „Journal of Economic Perspectives", Vol. 29, No. 3, pp. 3-30.

[3] Autor D., Acemoglu D. (2011), Skills, Tasks and Technologies: Implications for Employment and Earnings, [in:] O. Ashenfelter, D. Card (eds.), Handbook of Labor Economics, Elsevier, Vol. 4B, pp. 1043-1171.

[4] Avant R. (2014), The Third Great Wave, The Economist, The World Economy Special Report, October $4^{\text {th }}$.

[5] Babbage Ch. (1832), On the Economy of Machinery and Manufactures, Charles Knight, London.

[6] Biczyński S., Miedziński B. (red.), (1991), Stownik Ekonomiki i organizacji przedsiębiorstwa, PWE, Warszawa.

[7] Blaschke M., Cigaina M., Riss U.V., Shoshan I. (2017), Designing Business Models for the Digital Economy, [in:] G. Oswald, M. Kleinemeier (eds.), Shaping the Digital Enterprise: Trends and Use Cases in Digital Innovation and Transformation, Springer International Publishing, Cham, pp. 121-136.

[8] Bowles J. (2014), The Computerisation of European Jobs, In Bruegel, July, http://bruegel.org/2014/07/the-computerisation-of-european-jobs, access date: 17.01.2019.

[9] Bravermann H. (1998), Labor and Monopoly Capita. The Degradation or Work in the Twentieth Century, Monthly Review Press, New York.

[10] Bright J. (1958), Automation and Management, Division of Research Graduate School of Business Administration, Harvard University, Boston.

[11] Brynjolfsson E., McAfee A. (2014), The Second Machine Age: Work, Progress, and Prosperity in a Time of Brilliant Technologies, W.W. Norton \& Company, New York-London.

[12] Brzeziński M. (2002), Organizacja i sterowanie produkcja. Projektowanie systemów produkcyjnych i procesów sterowania produkcja, Agencja Wydawnicza Placet, Warszawa.

[13] Cline B., Henry M., Justice C. (2016), Rise of the robots, KPMG 2016, https://home.kpmg/content/dam/kpmg/ my/pdf/Rise\%20of\%20the\%20robots.pdf, access date: 13.11.2020.

[14] Coelli M., Borland J. (2016). Job Polarisation and Earnings Inequality in Australia, „Economic Record”, Vol. 92, No. 296, pp. 1-27.

[15] Dustmann C., Ludsteck J., Schonberg U. (2009), Revisiting the German Wage Structure, „The Quarterly Journal of Economics", Vol. 124, No. 2, pp. 843-881.

[16] Esposto A. (2008), Skill: An Elusive and Ambiguous Concept in Labour Market Studies, „Australian Bulletin of Labour", Vol. 34, No. 1, pp. 100-124.

[17] Frey C.B., Osborne M.A. (2013), The Future of Employment: How Susceptible are Jobs to Computerization? Working Paper Oxford Martin School, September 17.

[18] Godin B. (2006), The Knowledge-Based Economy: Conceptual Framework or Buzzword? „The Journal of Technology Transfer”, Vol. 31, No. 1, pp. 17-30. 
[19] Goldin C., Katz L.F. (1996), The Origins of TechnologySkill Complementarity, NBER Working Paper, No. 5657.

[20] Goos M., Manning A., Salomons A. (2009), Recent Changes in the European Employment Structure: The Roles of Technological Change, https://lirias.kuleuven.be/bitstream/123456789/256315/1/, access date: 25.01.2018.

[21] Green D., Sand B. (2015), Has the Canadian Labor Market Polarised? „Canadian Journal of Economics”, Vol. 48, No. 2, pp. 612-646.

[22] Harari Y.N. (2018), 21 lekcji na XXI wiek, Wydawnictwo Literackie.

[23] Lee K.F. (2017), Automation, Computerisation and Future Employment in Singapore, Munich Personal RePEc Archive Paper, No. 79961.

[24] Manyika J., Chui M., Miremadi M., Bughin J., George K., Willmott P., Dewhurst M. (2017), A Future That Works: Automation, Employment, and Productivity, McKinsey Global Institute, www.mckinsey.com/featured-insights/digital-disruption/mgi, access date: 25.01.2018.

[25] Martyniak Z. (red.), (1992), Wptyw postępu techniczno-organizacyjnego na poziom i strukturę trudności prac administracyjno-biurowych, Zakład Narodowy im. Ossolińskich - Wydawnictwo, Wrocław-Warszawa-Kraków.

[26] Michaels G., Natraj A., van Reenen J. (2014), Has ICT Polarized Skill Demand? Evidence from Eleven Countries over 25 Years, „Review of Economics and Statistics”, Vol. 96, No. 1, pp. 60-77.

[27] Mokyr J. (2002), The Gifts of Athena: Historical Origins of the Knowledge Economy, Princeton University Press, Princeton.

[28] Musso S. (2013), Labor in the Third Industrial Revolution, [in:] G. Dosi, L. Galambos (eds.), The Third Industrial Revolution in Global Business, Cambridge University Press, pp. 300-325.

[29] Nagarajah E. (2016), Hi Robot. What does Automation Mean for the Accounting Profession? „Accountants Today”, July/August, pp. 34-37.

[30] Naville P. (1968), Społeczne skutki automatyzacji. Problemy pracy i automatyzacji, Książka i Wiedza, Warszawa.

[31] Noble D.F. (1984), Forces of Production: A Social History of Industrial Automation, Knopf-Random House, New York.

[32] O'Connor D., Lunati M.R. (1999), Economic Opening and the Demand for Skills in Developing Countries: A Review of Theory and Evidence, Working Paper, No. 149, OECD Development Centre, OECD-OCDE.

[33] OECD (2017a), Getting Skills Right: Skills for Jobs Indicators, OECD Publishing, Paris.

[34] OECD (2017b), The Next Production Revolution: Implications for Governments and Business, OECD Publishing, Paris.

[35] Pajarinen M., Rouvinen P., Ekeland A. (2015), Computerization Threatens One-Third of Finnish and Norwegian Employment, ETLA Brief 34, pp. 1-8.

[36] Pilat Z., Klimasara W., Pachuta M., Słowikowski M., Smater M., Zieliński J. (2018), Możliwości praktycznego wprowadzania robotów wspótpracujących $w$ różnych technologiach wytwórczych realizowanych $w$ środowisku przemystowym, „Pomiary-Automatyka-Robotyka”, Nr 1, s. 59-65.

[37] Richard R.B. (2005), Industrialised Building Systems: Reproduction Before Automation and Robotics, „Automation in Construction", Vol. 14, No. 4, pp. 442-451.
[38] Rifkin J. (2011), The Third Industrial Revolution. How Lateral Power is Transforming Energy, the Economy and the World, Palgrave Macmillan, Basingstoke.

[39] Schwab K. (2017), The Fourth Industrial Revolution, Penguin, London.

[40] Simon H.A. (2007), Podejmowanie decyzji i zarządzania ludźmi w biznesie i administracji, wydanie IV, Wydawnictwo Helion, Gliwice.

[41] Snow Ch., Øystein C., Fjeldstad D., Langer A.M. (2017), Designing the Digital Organization, ,Journal of Organization Design", Vol 6., No. 7, pp. 1-13.

[42] Sobczak A. (2019), Developing a Robotic Process Automation Management Model, „Informatyka Ekonomiczna - Business Informatics", Vol. 2, No. 52, s. 85-100.

[43] Terzidis N., van Maarseveen R., Ortega-Argiles R. (2017), Employment Polarization in Local Labor Markets: The Dutch Case, CPB Netherlands Bureau for Economic Policy Analysis, CPB Discussion Paper, No. 358.

[44] Ure A. (1835), Philosophy of Manufactures, H.G. Bohn, London.

[45] Wang J., Caminada K., Goudswaard K., Wang Ch. (2015), Decomposing Income Polarization and Tax - Benefit Changes Across 31 European Countries and Europe Wide 2004-2012, Leiden University, Department of Economics, Leiden.

\section{Barriers and the Scope of Automation from the Perspective of Work Content}

\section{Summary}

The aim of the paper is to identify the importance and scope of work process automation. As part of the defined in this way intention, the concept of automation has been explained, referring in this regard to terms corresponding to the concept of automation. An increase in the number of publications on automation, robotisation and mechanisation has been shown based on the bibliometric study. On the basis of the review of the literature on the subject, phenomena describing the impact of technical progress on the content of work have been identified. In particular, the requirements imposed on employees in work processes and so the essence of three effects have been presented, including unskill-biased technical change, skill-biased technical change and talent-biased technical change. Next, the approaches enabling the estimation of the potential scope of automation of work processes and the risk of automation of individual professions have been indicated. These approaches may constitute a starting point for the development of a diagnostic tool enabling estimation of the potential scope of work subject to automation and identification of factors and job variables constituting barriers to automation of work processes.

\section{Keywords}

automation, robotisation, technical progress, work content 